\title{
Moderating Role of the Transformational Leadership in the Relationship between HRM Practices and Performance: A Study of ICT Companies of Malaysia
}

\author{
Nazanin Mansouri ${ }^{1}$ \\ ${ }^{1}$ ELM School, HELP University, Kuala Lumpur, Malaysia \\ Correspondence: Nazanin Mansouri, ELM Graduate School, HELP University, Kuala Lumpur, Malaysia. E-mail: \\ nazanin_mansouri89@yahoo.com
}

Received: April 11, 2016 Accepted: April 25, 2016 Online Published: June 21, 2016

doi:10.5539/ass.v12n7p1 URL: http://dx.doi.org/10.5539/ass.v12n7p1

\begin{abstract}
This paper primarily aims to highlight that transformational leadership influences the relationship between human resource management (HRM) practices. Extant research studies have revealed that HRM practices have noticeable potential to increase employees and organizations performance. However, this study proposes transformational leadership as moderator of the relationship between HRM practices and organization's performance. Prime HRM practices of this study consists of training, staffing, performance evaluation, reward system, and participation while transformational leadership have five components namely, vision, inspirational motivation, intellectual stimulation, personal recognition, and supportive leadership. With the purpose of emphasizing on the significance of underlying variables of this study, research problem is linked to Information and Communication Technology (ICT) companies in Malaysia.
\end{abstract}

Keywords: transformational leadership, HRM practices, ICT companies, HR framework, organizational performance, leadership, human resource

\section{Introduction}

\subsection{Background}

Information and communication technology (ICT) has become an indispensable part of the contemporary world in such a way that its pervasiveness transformed the technological as well as cultural aspects of our modern societies (Mentz et al., 2012).

However, this technological expansion has brought about a paradigm shift in the workforce criteria, calling for adjustments in skills and capabilities of professionals. Therefore the demand for qualified ICT professionals has remarkably increased but despite the numerous institutions providing education and training in this field, still they are unable to fulfill the requirements (Suhaimi et al., 2012). Therefore, fundamental changes are required to resolve the mismatch of supply and demand which is a concern for both business practitioners as well as academics.

Aspiring to achieve a knowledge-based economy, Malaysia has advanced rapidly in terms of ICT infrastructure development which constitutes a considerable part of its Vision 2020 (Lau \& Sim, 2008; Sin et al., 2010; Hassan et al., 2011; Bajunid, 2012; Bohari et al., 2013; Tang \& Tan, 2014). Recent studies in this area have revealed that one of the most underpinning factors in ICT is innovation (Toppeta, 2014; Peschl \& Fundneider, 2014) whereas it can impact organizational performance (particularly Balanced-Score Card perspectives as suggested by Kaplan and Norton (1995). Balanced-Score Card perspectives (BSC) is considered to be one of the most reliable measures in performance evaluation (Hojabri et al., 2013; Borousan et al., 2011), according to which, performance should be evaluated from four different perspectives including customer satisfaction, financial performance, internal process, and learning and growth. Subsequently, given that three of the above mentioned factors are non-financial, and also the impact of innovation on non-financial factors has been well established in the literature, it can be concluded that innovation significantly impact the organizational performance (Kanter, 2015; Senge, 2014; Ellis \& Goodyear, 2013; Aguilera-Caracuel \& Ortiz-de-Mandojana, 2013).

However, given the importance of innovation in ICT and its remarkable impact on the organizational 
performance, there seems to be a lack of attention to this issue by business practitioner and researchers particularly in Malaysian context.

In the meantime the resource-based view (RBV) of the firm has been established as one of the main approaches to strategy formulation for the development of sustainable competitive advantage. RBV emphasizes on the link between internal resources of the firm particularly human resource (HR) and its performance (Barney, 1991) which can bring competitive advantage to the firm. This fact has been highlighted in many studies for instance; employing a meta-analysis Huselid (1995) demonstrated the impact of HR on financial performance; similarly Chen and Huang (2009) revealed that HRM practices can influence knowledge management capacity and innovation performance. However in recent studies the direct impact of HR on knowledge sharing and innovation has been demonstrated (Manafi \& Subramaniam, 2015a).

Subsequently the significant role of knowledge in prosperity of firm by inducing innovation has been emphasized in the literature. One of the main causes of this focus on knowledge as one of the most critical resources of the firm is due to the fact that the economic change of material-based production to information-based production created a revaluation of the firm (Manafi \& Subramaniam, 2015a). Therefore the RBV can be translated into Knowledge based view (KBV) of the firm supporting the main assumptions as not being imitated easily and is heterogeneous. (Grant, 1996; Cabrera-Suarez et al., 2001; Felin et al., 2007; Blome et al., 2014). In this way both RBV and KBV bring about evidence that imply the impact of HRM on general performance of the firm and particularly innovation.

Nevertheless research has shown that the missing link to improve this relation is transformational leadership. This fact has been argued by Manafi and Subramaniam (2015a) who emphasized the complementary role of transformational leadership on the relationship between HRM practices and firm performance.

The complementary nature of this link in signified by the fact that HRM practices improves individual skills of employees while transformational leadership enhances factors such as motivation and inspiration; therefore imbalance of these two elements can create a gap which hinders the growth and performance of the firm by producing employees who either lack the necessary skills or feel demotivated (Braun et al., 2013; Noruzy et al., 2013). Despite the significance and importance of the above mentioned issue for development of the firms which can eventually contribute to the economy and well-being of society, there are very few, if any, studies which delved into the matter and investigate its different aspects.

\section{Literature Review}

\subsection{HRM Practices}

According to Schuler et al., (1995), Wright and Snell (1991) and Schuler and Mac Millan (1984), human resources are considered to be all the organizational activities in order to manage human resource pool (HR) and ensure that this resources are operating appropriately in such a way that meet the organizational goals and objectives. Table 1 demonstrates different aspects of HRM practices pointed out by experts and researchers in this field.

Table 1. Various HRM practices defined by various scholars

\begin{tabular}{ll}
\hline Researchers & HRM practices \\
\hline \multirow{2}{*}{ Huselid (1995) } & $\begin{array}{l}\text { Performance appraisal; Personal selection; Job design; Incentive } \\
\text { compensation; Grievance procedures; Attitude assessment; Information } \\
\text { sharing; Participation; Recruitment efforts; Promotion; Training }\end{array}$ \\
& $\begin{array}{l}\text { Selective hiring; Employee security; Participation; Training; Compensation; } \\
\text { Profit sharing; Reduced status distinctions }\end{array}$ \\
& $\begin{array}{l}\text { Planning; Staffing; Compensation; Performance appraisal; Training and } \\
\text { development }\end{array}$ \\
Huang (2000) & $\begin{array}{l}\text { Placement; Recruitment and selection; Training; Performance appraisal; } \\
\text { Compensation; Grievance procedures; Promotion; Pension and social security }\end{array}$ \\
Chen \& Huang (2009); Manafi & $\begin{array}{l}\text { Staffing; Training; Performance appraisal; Reward and compensation; } \\
\text { \& Subramaniam (2015a; b) }\end{array}$ \\
Participation & $\begin{array}{l}\text { Healthy; Safe; Happy work place; Feedback mechanism; Open house } \\
\text { discussion; Open management; Delight employees with unexpected; etc }\end{array}$ \\
\hline
\end{tabular}




\subsection{HRM Practices and Organizational Performance}

The positive and significant impact of HRM on the firm performance is well established in the literature. The scholars found out that there is a positive and significant relationship between HRM practices and organizational performance (MacDuffie, 1995; Gerhart \& Becker, 1996; Delery \& Doty, 1996; Huselid, 1995). In their studies, these researchers also attempted to highlight different aspects of innovative HRM practices and also compare these aspects in terms of pros and cons to enable practitioners opt the most appropriate approach. According Doty and Delery and Doty (1996), since the introduction of HRM many organizations tried to adopt and employ these practices and most of them reported lower costs and higher revenue as a result of these measures, and subsequently a considerable attention was drawn to this field.

Furthermore Rozell and Terpstra (1993) studied data from the number of 2012 companies in 1993 with regard to human resource practices such as: having gauging system for return on investment (ROI) and recruitment source, validity gauging regarding pre-employment assessment, standardized and structured interviews, intelligence assessment and biographic Information or Weighted Application. Their study revealed that those firms employing HRM practices obtain higher profit levels. They asserted that there is a significant and positive relationship between level of implementation of five different policies for both staffing and financial performance of organization. They have conducted cross sectional studies comparing annual growth of the sample population before and after implementation of HRM practices and reported improvements in performance and growth induced by these measures. They also compared their data for different countries and found out that the rate of change differs to a certain extent for each country. Similarly Chen and Huang (2009) examined the impact of training, performance appraisal, staffing, participation and reward system on knowledge management capacity and technical innovation.

Manafi and Subramaniam (2015a) utilized different theories including RBV, social capital, social exchange and transformational leadership in order to study the relationship between various HRM practices and transformational leadership with knowledge sharing and innovation. Their results demonstrated a mediating role for knowledge sharing. In addition they concluded that knowledge has a vital impact on improving the innovation.

In another attempt to provide a new method for choosing the best HRM practices Manafi and Subramaniam (2015b) came up with the conclusion that through appropriate selection and also implementing HRM practices, performance of an organization can be controlled and eventually improved. They evaluated the firm performance according to perspectives of BSC. Their proposed method was developed based on fuzzy logic neural network and AHP method.

According to the findings presented in above mentioned studies, it can be concluded that effectiveness of HRM practices can vary in different industries. In addition considering the perspectives of BSC can be a helpful approach to evaluate performance. Innovation also has been indicated as an influential factor on the performance and therefore can be considered as an additional dimension while considering performance evaluation. However it was mentioned in the aforementioned research that transformational leadership has a complementary role in the relationship between HRM practices and firm performance (Manafi \& Subramaniam, 2015a). Accordingly this research attempts to investigate the moderating role of the transformational leadership in the relationship between HRM practices and performance. This is a contemporary issue which did not receive sufficient attention. In following sections a brief list of definitions to transformational leadership is presented.

\subsection{Transformational Leadership}

Leadership and transformational leadership constructs have been discussed by many scholars (Bycio et al. 1995; Tejeda, Scandura, \& Pillai, 2001; Carless, 1998; Avolio et al., 1999) who studied the impact of transformational leadership on different factors such as knowledge sharing (Manafi \& Subramaniam, 2015a; Garcia-Morales et al., 2012), financial performance (Garcia-Morales et al., 2008; Grant, 2012), innovation (Manafi \& Subramaniam, 2015a; Vaccaro et al., 2012) and job satisfaction (Yang, 2012; Braun et al., 2013). This section tries to discuss each one of them in detail and transformational leadership components in recent studies (Manafi \& Subramaniam, 2015a; Arzi \& Farahbod, 2014) will be presented separately. However it is inevitable to review developed theoretical models by Bass (1985) and identifying five sub-dimensions of transformational leadership which can demonstrate validity levels in which not related concepts will become not relevant to each other. Additionally, the formulated theoretical model by Bass could be employed to achieve better results.

\subsubsection{Vision}

According to Bass (1985), one of the most critical transformational leadership dimensions is charisma. Empirical 
findings suggest that charisma is positively and significantly related to effectiveness though the mechanism of leader satisfaction (Kroeck, Sivasubramaniam, \& Lowe, 1996). Business practitioners played a key role to describing the concept of charisma (Beyer, 1999; Barbuto, 1997). Particularly Beyer studied critical charisma components which have been neglected dramatically. Weber (1968) introduced five dimensions for charisma namely ideas suggesting radical solutions to different problems, social crisis, gifted person, a group of followers who are interested in exceptional people who believe that leaders have transcendent powers as well as extraordinary gifs of leaders and validity of talents together with various repeated achievements. Generally, as noted in transformational model, charisma could not incorporate all of the mentioned components altogether because there are other factors including impacts of surrounding context of followers and leaders, individual qualities connected to charisma and relationship among charismatic leaders and followers as well as transcendent powers of leader that have not been explored yet in previous researches. This vision is considered as the leadership's critical factor that is incorporated in logical charismatic framework. According to House (1977) vision is known as an appropriate factor to reflect shared values among various stakeholders. Besides McClelland (1975) explained that vision leads to fulfillment of organizational objectives and values through encouraging people to adapt all appropriate behaviors that matches the charisma or attractiveness of leaders.

In this research, vision could be considered as the mental and implicit expression or image which is produced through ideals for future and is supposed to create value in organizations. As Weber (1968) mentioned, a good vision is known as a basic factor which impacts charisma. According to House (1997) charismatic leaders show behaviors including ideology articulation which improves task focus, goal clarity as well as value congruence.

\subsubsection{Inspirational Communication}

Bass (1985) asserted that charismatic leaders use inspirational allures and emotional talks to raise employees' motivation which results in employees to give up their own interest for the sake of betterment in the performance of firm. Then, Bass (1999) explained that charisma and inspirational motivation are demonstrated if leader is able to envision a desirable future for followers and articulates how to reach it effectively, he presented an example in this regard such as setting high standards of performance and show determination and confidence both in different planned tasks. This explains that vision and inspirational motivation can probably be joined together as one single construct.

Although many experts recommended the idea to differentiate between inspirational motivation and vision (McClelland, 1975), in following sections a set of theoretical rationale will be presented to differentiate between inspirational leadership constructs and charisma's vision components:

According to Downton (1973) inspirations are powers or acts to stimulate intellect or emotions. In addition Yuki (1981) noted that inspiration is the degree to which a leader raises enthusiasm in its subordinates to perform their tasks and also build up confidence among his subordinates by making positive comments to perform their assignments successfully and fulfill the team objectives in the best possible way.

\subsubsection{Supportive Leadership}

The chain of studies in this filed has led to the introduction of a concept named supportive leadership. For example Avolio and Bass (1995, p. 202) explained that better results will be achieved if the leader shows more individualized consideration via demonstrating a positive and general support for followers' attempts.

The factor which thoroughly distinguishes transformational leadership from other newly developed leadership theories is "Individualized Consideration". Bass (1985) mentioned that individualized consideration occurs if a leader takes developmental orientation which means they try to have more development within organizations. Accordingly, he will show individualized consideration to followers and provides appropriate reactions to their unique needs.

In addition, there are a lot of scholars who study transformational leadership who also emphasized on supportive leadership. As Podsakoff et al. (1990) noted, individualized support is considered as the behavior of leaders in which they consider their followers and their specific needs.

\subsubsection{Intellectual Stimulation}

Intellectual stimulation is one of the most significant and underdeveloped aspects of transformational leadership as explained by Lowe et al., (1996). However, this leadership dimension includes many behavioral patterns that can result in inducing interest among the followers toward organizational goals and issues which eventually lead to the condition where try to improve their capabilities to solve problems through using new approaches and techniques (Bass, 1985). It was found out that intellectual stimulation clearly impacts ability of followers to better conceptualize, comprehend and also analyze different issues and then provide good solutions for their 
organizations' issues and challenges (Bass \& Avolio, 1990). This aspect was not studied in depth in previous researches; despite the fact that it includes a more comprehend class of behaviors compared to other sub-dimensions of transformational leadership.

\subsubsection{Supportive Leadership}

Theoretical evidence suggest that there is a significant and positive relationship between transactional leadership and transformational leadership sub-dimensions through which transactional leadership helps managers with the system of contingent reward and punishment. According to Bass (1985) a positive expression for good employees works even better than extra payment and promotion. He suggests that commendations are the best examples of such contingent reward behaviors. Based on empirical results in literature review, contingent rewards have positive and significant relationship with transformational leadership and which can be employed for transformational sub-dimensions as well (Tepper \& Percy, 1994; Den Hartog, Van Muijen, \& Koopman, 1997).

\section{Proposed Framework and Methodology}

The impact of transformational leadership on performance of organizations has been the subject of study for a great number of recent research studies in this area (Dyer et al., 2009; Pieterse et al., 2010; Wang et al., 2011; Grant, 2012; Moynihan et al., 2012). These researchers took into account various aspects of performance including learning, innovation, and internal process. However all these relationships are considered individually between the mentioned variables therefore integrating these variables into one model and investigating their interrelationship is found to be a gap in the extant literature. In addition, impacts of learning and innovation on non-financial performance were not efficiently reviewed in these investigations despite the fact that there is enough evidence on the fact that HRM practices can impact performance. Accordingly, the following conceptual framework is proposed based upon the assumptions in RBV, KBV, and transformational theory:

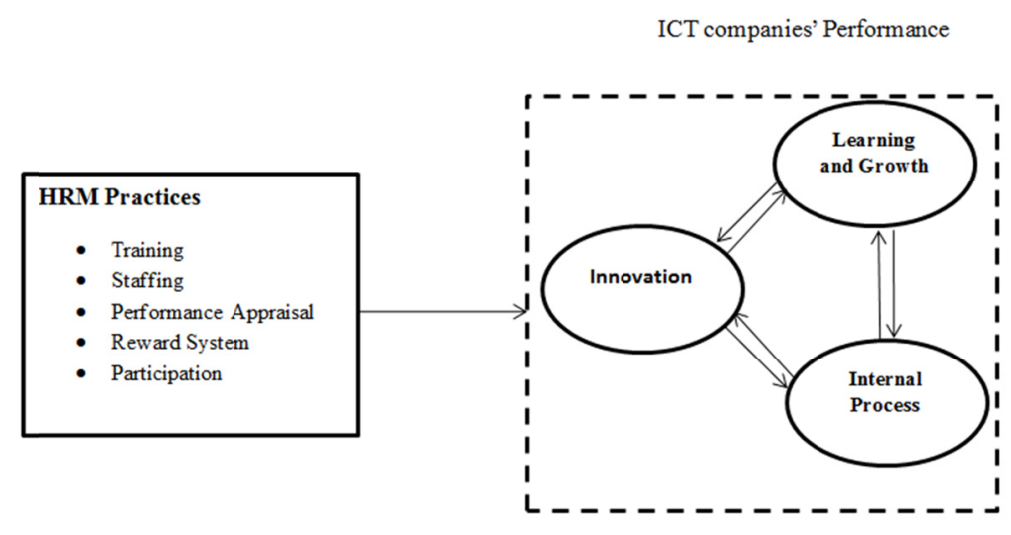

Figure 1. Proposed framework

In order to test the relationship between constructs in the above conceptual framework, a quantitative approach will be employed. Accordingly research hypotheses are developed as follows (each hypothesis should be break down into some sub-hypothesis).

H1: HRM practices have significant and positive relationship with Performance

H2: Transformational leadership has a significant and positive relationship with Performance

H3: Transformational leadership moderates the relationship between HRM practices and performance

H4: Innovation has as significant and positive effect on learning and growth

H5: Innovation has as significant and positive effect on internal process

H6: Internal process has as significant and positive effect on learning and growth

H7: Learning and growth has as significant and positive effect on internal process

H8: Learning and growth has as significant and positive effect on innovation

H9: Internal process has as significant and positive effect on learning and growth 


\section{Conclusion}

There are a great number of evidences to prove that human resource management (HRM) practices have a potential to affect organization's performance significantly. Theories namely KBV and RBV are used to justify this effect. Organizational performance of knowledge based companies can be measured by innovation, internal process, learning, and growth which are logical interactions between these dimensions. After reviewing extant research, it is reasonable to claim that the relationship between HRM practices and company's performance can be affected by transformational leadership. In other words, transformational leadership has a moderating role; hence future studies can test the proposed framework of this study in ICT companies in Malaysia. Moreover, this framework can be tested in other knowledge based industries.

\section{References}

Adam Suhaimi, M., Rabiul Hasan, M., Hussin, H., \& Shah, A. (2012). Information and communication technology workforce employability in Malaysia. Campus-Wide Information Systems, 29(2), 80-89. http://dx.doi.org/10.1108/10650741211212340

Aguilera-Caracuel, J., \& Ortiz-de-Mandojana, N. (2013). Green Innovation and Financial Performance An Institutional Approach. Organization \& Environment, 26(4), 365-385. http://dx.doi.org/10.1177/1086026 613507931

Arzi, S., \& Farahbod, L. (2014). Relationship of Transformational and Transactional Leadership Style with Job Satisfaction. Interdisciplinary Journal of Contemporary Research in Business, 6(3), 188-204.

Avolio, B. J., \& Bass, B. M. (1995). Individual consideration viewed at multiple levels of analysis: A multi-level framework forexamining the influence of transformational leadership. The Leadership Quarterly, 6, 199-218. http://dx.doi.org/10.1016/1048-9843(95)90035-7

Avolio, B. J., Bass, B. M., \& Jung, D. I. (1999). Re-examining the components of transformational and transactional leadership using the Multifactor Leadership Questionnaire. Journal of Occupational and Organizational Psychology, 72, 441-462. http://dx.doi.org/10.1348/096317999166789

Barney, J. (1991). Firm resources and sustained competitive advantage. Journal of Management, 17(1), 99-120. http://dx.doi.org/10.1177/014920639101700108

Bajunid, I. A. (2012). The transformation of Malaysian society through technological advantage: ICT and education in Malaysia. Journal of Southeast Asian Education, 2(1).

Barbuto, J. E. (1997). Taking the charisma out of transformational leadership. Journal of Social Behavior and Personality, 12(3), 689-697.

Bass, B. (1985). Leadership and performance beyond expectations. New York: The Free Press.

Bass, B. M. (1999). Two decades of research and development in transformational leadership. European Journal of Work and Organizational Psychology, 8(1), 9-32. http://dx.doi.org/10.1080/135943299398410

Bass, B. M., \& Avolio, B. J. (1990). The implications of transactional and transformational leadership for individual, team, organizational development. Research in Organizational Change and Development, 4, 231-272.

Becker, B., \& Gerhart, B. (1996). The impact of human resource management on organizational performance: Progress and prospects. Academy of Management Journal, 39(4), 779-801. http://dx.doi.org/10.2307/ 256712

Beyer, J. M. (1999). Taming and promoting charisma to change organizations. The Leadership Quarterly, 10(2), 307-330. http://dx.doi.org/10.1016/S1048-9843(99)00019-3

Blome, C., Schoenherr, T., \& Eckstein, D. (2014). The impact of knowledge transfer and complexity on supply chain flexibility: A knowledge-based view. International Journal of Production Economics, 147, 307-316. http://dx.doi.org/10.1016/j.ijpe.2013.02.028

Bohari, A. M., Cheng, W. H., \& Fuad, N. (2013). An analysis on the competitiveness of halal food industry in Malaysia: An approach of SWOT and ICT strategy. Geografia: Malaysian Journal of Society and Space, 9(1), 1-11.

Borousan, E., Hojabri, R., Manafi, M., \& Hooman, A. (2011). Balanced Scorecard: A tool for measuring and modifying IT Governance in Healthcare organizations. International Journal of Innovation, Management and Technology, 2(2), 141. 
Braun, S., Peus, C., Weisweiler, S., \& Frey, D. (2013). Transformational leadership, job satisfaction, and team performance: A multilevel mediation model of trust. The Leadership Quarterly, 24(1), 270-283. http://dx.doi.org/10.1016/j.leaqua.2012.11.006

Bycio, P., Hackett, R. D., \& Allen, J. S. (1995). Further assessments of Bass' 1985 conceptualization of transactional and transformational leadership. Journal of Applied Psychology, 80(4), 468-478. http://dx.doi.org/10.1037/0021-9010.80.4.468

Cabrera-Suárez, K., De Saa-Perez, P., \& García-Almeida, D. (2001). The succession process from a resource-and knowledge-based view of the family firm. Family Business Review, 14(1), 37-46. http://dx.doi.org/10.1111/j. 1741-6248.2001.00037.x

Carless, S. A. (1998). Assessing the discriminant validity of transformational leadership behaviour as measured by the MLQ. Journal of Occupational and Organizational Psychology, 71, 353-358. http://dx.doi.org/10. 1111/j.2044-8325.1998.tb00681.x

Chen, C. J., \& Huang, J. W. (2009). Strategic human resource practices and innovation performance-The mediating role of knowledge management capacity. Journal of Business Research, 62(1), 104-114. http://dx.doi.org/10.1016/j.jbusres.2007.11.016

Delery, J. E., \& Doty, D. H. (1996). Modes of theorizing in strategic human resource management: Tests of universalistic, contingency, and configurational performance predictions. Academy of Management Journal, 39(4), 802-835. http://dx.doi.org/10.2307/256713

Den Hartog, D. N., Van Muijen, J. J., \& Koopman, P. L. (1997). Transactional versus transformational leadership: An analysisof the MLQ. Journal of Occupational and Organizational Psychology, 70, 19-34. http://dx.doi.org/10.1111/j.2044-8325.1997.tb00628.x

Downton, J. V. (1973). Rebel leadership: Commitment and charisma in the revolutionary process. New York: The Free Press.

Dyer, J. R., Johansson, A., Helbing, D., Couzin, I. D., \& Krause, J. (2009). Leadership, consensus decision making and collective behaviour in humans. Philosophical Transactions of the Royal Society B: Biological Sciences, 364(1518), 781-789. http://dx.doi.org/10.1098/rstb.2008.0233

Ellis, R., \& Goodyear, P. (2013). Students' experiences of e-learning in higher education: The ecology of sustainable innovation. Routledge.

Felin, T., \& Hesterly, W. S. (2007). The knowledge-based view, nested heterogeneity, and new value creation: Philosophical considerations on the locus of knowledge. Academy of Management Review, 32(1), 195-218. http://dx.doi.org/10.5465/AMR.2007.23464020

García-Morales, V. J., Jiménez-Barrionuevo, M. M., \& Gutiérrez-Gutiérrez, L. (2012). Transformational leadership influence on organizational performance through organizational learning and innovation. Journal of Business Research, 65(7), 1040-1050. http://dx.doi.org/10.1016/j.jbusres.2011.03.005

García-Morales, V. J., Lloréns-Montes, F. J., \& Verdú-Jover, A. J. (2008). The Effects of transformational leadership on organizational performance through knowledge and innovation. British Journal of Management, 19(4), 299-319. http://dx.doi.org/10.1111/j.1467-8551.2007.00547.x

Grant, A. M. (2012). Leading with meaning: Beneficiary contact, prosocial impact, and the performance effects of transformational leadership. Academy of Management Journal, 55(2), 458-476.

Grant, R. M. (1996). Toward a knowledge-based theory of the firm. Strategic management journal, 17(S2), 109-122. http://dx.doi.org/10.1002/smj.4250171110

Hassan, M. A., Samah, B. A., Shaffril, H. A. M., \& D’Silva, J. L. (2011). Perceived usefulness of ICT usage among JKKK members in Peninsular Malaysia. Asian Social Science, 7(10), 255. http://dx.doi.org/10.5539/ ass.v7n10p255

Hojabri, R., Manafi, M., Eftekhar, F., Ghassemzadeh, H., Sharifi, M., \& Kaliannan, M. (2013). Effective methods for health care organizations: An evaluation of excellence models. African Journal of Business Management, 7(27), 2665-2675. http://dx.doi.org/10.5897/AJBM11.2747

House, R. J. (1977). A 1976 theory of charismatic leadership. In J. G. Hunt, \& L. L. Lawson (Eds.), Leadership: The cuttingedge ( pp. 189-207). Carbondale: Southern Illinois University Press.

Huang, T. C. (2000). Are the human resource practices of effective firms distinctly different from those of poorly 
performing ones? The International Journal of Human Resource Management, http://dx.doi.org/10.1080/ 095851900339945

Huselid, M. A. (1995). The impact of human resource management practices on turnover, productivity, and corporate financial performance. Academy of Management Journal, 38(3), 635-672. http://dx.doi.org/10. $2307 / 256741$

Kanter, R. M. (2015). From spare change to real change: The social sector as beta site for business innovation. Havard Business Review.

Kaplan, R. S., \& Norton, D. P. (1995). Putting the balanced scorecard to work. Performance measurement, management, and appraisal sourcebook, 66.

Lau, B. T., \& Sim, C. H. (2008). Exploring the extent of ICT adoption among secondary school teachers in Malaysia. International Journal of Computing and ICT research, 2(2), 19-36.

Lowe, K. B., Kroeck, K. G., \& Sivasubramaniam, N. (1996). Effectiveness correlates of transformational and transactional leadership: A meta-analytic review of the MLQ literature. The Leadership Quarterly, 7(3), 385-425. http://dx.doi.org/10.1016/S1048-9843(96)90027-2

MacDuffie, J. P. (1995). Human resource bundles and manufacturing performance: Organizational logic and flexible production systems in the world auto industry. Industrial \& labor relations review, 48(2), 197-221. http://dx.doi.org/10.1177/001979399504800201

Manafi, M., \& Subramaniam, I. D. (2015a). Relationship between Human Resources Management Practices, Transformational Leadership, and Knowledge Sharing on Innovation in Iranian Electronic Industry. Asian Social Science, 11(10), 358. http://dx.doi.org/10.5539/ass.v11n10p358

Manafi, M., \& Subramaniam, I. D. (2015b). Balancing Performance by Human Resource Management Practices. Asian Social Science, 11(10), 386. http://dx.doi.org/10.5539/ass.v11n10p386

Mentz, E., Bailey, R., Havenga, M., Breed, B., Govender, D., Govender, I., ... \& Dignum, V. (2012). The diverse educational needs and challenges of Information Technology teachers in two black rural schools. Perspectives in Education, 30(1), 70-78.

McClelland, D. C. (1975). Power: The inner experience. New York: Irvington Publishers.

Moynihan, D. P., Pandey, S. K., \& Wright, B. E. (2012). Setting the table: How transformational leadership fosters performance information use. Journal of Public Administration Research and Theory, 22(1), 143-164. http://dx.doi.org/10.1093/jopart/mur024

Noruzy, A., Dalfard, V. M., Azhdari, B., Nazari-Shirkouhi, S., \& Rezazadeh, A. (2013). Relations between transformational leadership, organizational learning, knowledge management, organizational innovation, and organizational performance: an empirical investigation of manufacturing firms. The International Journal of Advanced Manufacturing Technology, 64(5-8), 1073-1085. http://dx.doi.org/10.1007/s00170012-4038-y

Peschl, M. F., \& Fundneider, T. (2014). Designing and enabling spaces for collaborative knowledge creation and innovation: From managing to enabling innovation as socio-epistemological technology. Computers in Human Behavior, 37, 346-359. http://dx.doi.org/10.1016/j.chb.2012.05.027

Pieterse, A. N., Van Knippenberg, D., Schippers, M., \& Stam, D. (2010). Transformational and transactional leadership and innovative behavior: The moderating role of psychological empowerment. Journal of Organizational Behavior, 31(4), 609-623. http://dx.doi.org/10.1002/job.650

Pfeffer, J. (1998). The human equation: Building profits by putting people first. Harvard Business Press.

Podsakoff, P. M., MacKenzie, S. B., Moorman, R. H., \& Fetter, R. (1990). Transformational leader behaviors and their effects on followers' trust in leader, satisfaction, and organizational citizenship behaviors. The Leadership Quarterly, 1(2), 107-142. http://dx.doi.org/10.1016/1048-9843(90)90009-7

Schuler, R. S., \& Jackson, S. E. (1995). Understanding human resource management in the context of organizations and their environment. Annual Review of Psychology, 46(1), 237-264.

Schuler, R. S., \& MacMillan, I. C. (1984). Gaining competitive advantage through human resource management practices. Human Resource Management, 23(3), 241-255. http://dx.doi.org/10.1002/hrm.3930230304

Senge, P. M. (2014). The dance of change: The challenges to sustaining momentum in a learning organization. Crown Business. 
Sin Tan, K., Choy Chong, S., Lin, B., \& Cyril Eze, U. (2010). Internet-based ICT adoption among SMEs: Demographic versus benefits, barriers, and adoption intention. Journal of enterprise information management, 23(1), 27-55. http://dx.doi.org/10.1108/17410391011008897

Tang, C. F., \& Tan, B. W. (2014). The linkages among energy consumption, economic growth, relative price, foreign direct investment, and financial development in Malaysia. Quality \& Quantity, 48(2), 781-797. http://dx.doi.org/10.1007/s11135-012-9802-4

Tejeda, M. J., Scandura, T. A., \& Pillai, R. (2001). The MLQ revisited: Psychometric properties and recommendations. The Leadership Quarterly, 12, 31-52. http://dx.doi.org/10.1016/S1048-9843(01)00063-7

Tepper, B. J., \& Percy, P. M. (1994). Structural validity of the Multifactor Leadership Questionnaire. Educational and Psychological Measurement, 54(3), 734-744. http://dx.doi.org/10.1177/0013164494054003020

Terpstra, D. E., \& Rozell, E. J. (1993). The relationship of staffing practices to organizational level measures of performance. Personnel Psychology, 46(1), 27-48. http://dx.doi.org/10.1111/j.1744-6570.1993.tb00866.x

Tessema, M., \& Soeters, J. (2006). Challenges and prospects of HRM in developing countries: testing the HRM-performance link in Eritrean civil service. International Journal of Human Resource Management, 17(1), 86-105. http://dx.doi.org/10.1080/09585190500366532

Toppeta, D. (2014). The Smart City Vision: How Innovation and ICT Can Build Smart. Livable”, Sustainable Cities", The Innovation Knowledge Foundation. Retrieved from http://www.intaaivn.org/images/cc/ Urbanism/background\%20documents/Toppeta_Report_005_2010.pdf

Vaccaro, I. G., Jansen, J. J., Van Den Bosch, F. A., \& Volberda, H. W. (2012). Management innovation and leadership: The moderating role of organizational size. Journal of Management Studies, 49(1), 28-51. http://dx.doi.org/10.1111/j.1467-6486.2010.00976.x

Wang, G., Oh, I. S., Courtright, S. H., \& Colbert, A. E. (2011). Transformational leadership and performance across criteria and levels: A meta-analytic review of 25 years of research. Group \& Organization Management, 36(2), 223-270. http://dx.doi.org/10.1177/1059601111401017

Weber, M. (1968). Politics as a Vocation (pp. 91-92). Philadelphia: Fortress Press.

Wright, P. M., \& Snell, S. A. (1991). Toward an integrative view of strategic human resource management. Human Resource Management Review, 1(3), 203-225. http://dx.doi.org/10.1016/1053-4822(91)90015-5

\section{Copyrights}

Copyright for this article is retained by the author(s), with first publication rights granted to the journal.

This is an open-access article distributed under the terms and conditions of the Creative Commons Attribution license (http://creativecommons.org/licenses/by/3.0/) 